\title{
The relationship between forest fragmentation and the potential geographical distribution of psittacids (Psittaciformes: Psittacidae) in the Yucatán Peninsula, Mexico
}

\author{
Alexis Herminio Plasencia-Vázquez ${ }^{1}$, Griselda Escalona Segura ${ }^{2}$ \& Yarelys Ferrer Sánchez ${ }^{3}$ \\ 1. Universidad Autónoma de Campeche. Av. Agustín Melgar S/N entre Calle 20 y Juan de la Barrera. Col. Buenavista. \\ CP 24039, San Francisco de Campeche, Campeche; México; alexpla79@gmail.com \\ 2. El Colegio de la Frontera Sur (ECOSUR), Unidad Campeche. Av. Rancho Polígono 2-A, Ciudad Industrial de Lerma, \\ C.P. 24500. Lerma, Campeche, Mexico; gescalon@ecosur.mx \\ 3. Facultad de Ciencias Ambientales, Universidad Técnica Estatal de Quevedo, km 1 1⁄2 vía Quevedo-Santo Domingo, \\ Quevedo, Los Ríos, Ecuador; yferrersanchez@gmail.com
}

Received 06-X-2016. Corrected 10-VII-2017. Accepted 09-VIII-2017.

\begin{abstract}
Parrots are a seriously threatened group because of the illegal pet trade, their habitat fragmentation and the destruction of tropical forests. This study aimed to determine the relationship between forest fragmentation and the geographic potential distribution of parrot species in the Yucatan Peninsula, Mexico. The research was carried out in the Mexican portion of the Yucatan Peninsula Biotic region, which includes the states of Campeche, Quintana Roo and Yucatan. We worked with the eight species of psittacids that inhabit the selected areas: Eupsittula nana, Amazona albifrons, Amazona xantholora, Amazona autumnalis, Pionus senilis, Pyrilia haematotis, Amazona oratrix and Amazona farinosa. For these species, we used the potential geographical distribution maps that were obtained through the Maximum Entropy algorithm, published in 2014. To measure the levels of forest fragmentation in the Peninsula, we employed the land use and vegetation maps from series IV (2007-2010) of the National Institute of Statistics and Geography. We calculated different landscape metrics at 100 sites randomly distributed within the predicted presence and absence areas for the species. Multivariate methods were used to shorten dimensionality in the analysis, as well as to explore the observed patterns. We did not find any pattern regarding the number of variables that contribute to the logistic regression models (LR) and the size of the parrots' potential geographical distribution area within the Peninsula. For Pyrilia haematotis and Amazona oratrix, the fragmentation variables used did not seem to have any relationship with their potential geographical distribution in the Peninsula (intersection, $\operatorname{Pr}<0.0001$ ). Only for Eupsittula nana, Amazona xantholora and Pionus senilis, we found that the mean patch edge, the mean shape index and the mean perimeterarea ratio were important to determine their potential distribution patterns, respectively; and, in general, the variables indicated the preferences of these parrots to occupy larger habitat patches. Parrots must be given a special care and protection within the states of Campeche and Quintana Roo, since there are areas with high parrot diversity and are importantly affected by human activities. The best recommendation for managers and users of protected areas within the Yucatan Peninsula is that extensive areas of forest should be maintained in order to guarantee the suvival of psittacid populations. Rev. Biol. Trop. 65 (4): 1470-1482. Epub 2017 December 01.
\end{abstract}

Key words: conservation, threatened species, environmental factors, ecological niche models, parrots, Southeastern Mexico.

Forest fragmentation is one of the main anthropogenic factors that threaten bird conservation (Bregman, Sekercioglu, \& Tobias, 2014). In addition to habitat loss, a reduction in the mean size of the remaining forest patches can also act as a limiting factor on bird populations (Davis, 2004). Although numerous studies have been carried out on fragmentation, these tend to be difficult to interpret since they have been conducted at the patch, but not at the landscape scale (Fahrig, 2003). The landscape, from the ecological point of view, 
is a heterogeneous surface that contains a mosaic of patches or land use types (Arroyo \& Fahrig, 2014). Fragmentation is a process that occurs on the landscape scale (McGarigal \& Cushman, 2002), thus, when studies are conducted at the smaller patch level, it is difficult to make interpretations at the larger scale, at which fragmentation is taking place (Brennan, Bender, Contreras, \& Fahrig, 2002).

Responses to fragmentation vary between different bird groups or species (Visco et al., 2015; Uezu \& Metzger, 2016), and forest bird responses to fragmentation may be highly species/guild-specific (Lees \& Peres, 2009). For example, most frugivore species disappear from forest fragments after their isolation and few persist in small fragments surrounded by secondary growth forest (Cintra, Magnusson, \& Albernaz, 2013). Some landscape attributes (e.g. composition and spatial arrangement) and behavioral attributes of the species (e.g. mobility or dispersal ability) may interact to determine the species response to fragmentation (Major, Christie, \& Gowing, 2001). Moreover, birds with different sensitivity to fragmentation display contrasting responses to landscape dynamics (Metzger et al., 2009; Uezu \& Metzger, 2016). It has also been found that, some effects in bird species sensitive to fragmentation, have a 25 year time-lag to landscape changes, reinforcing the idea that it is not enough to conserve the present landscape structure to maintain those species in the long term (Uezu \& Metzger, 2016). On the other hand, relative effects of habitat amount and fragmentation are scale dependent, and the effects of habitat fragmentation depend on the size of the landscape considered (Smith, Fahrig, \& Francis, 2011).

Among forest birds, psittacids are seriously threatened due to the illegal pet trade (Marín et al., 2012) as well as the destruction and fragmentation of their habitats (Snyder, McGowan, Gilardi, \& Grajal, 2000). Nonetheless, parrots are highly mobile species able to move among forest patches (Renton, 2001), therefore studies of fragmentation effects on birds at the patch level may not be applicable to parrots. However, parrots can be affected by changes that occur in the characteristics of their habitats and their extension, even if they can move among distant forest patches (Tella et al., 2016). Different species of parrots and parakeets select areas with a high proportion of forest, and avoid areas with low forest cover (Legault, Chartendrault, Theuerkauf, Rouys, \& Barre, 2011). Nevertheless, other species are capable of exploiting some of the resources present in the landscape matrix, surrounding the forest fragments, and even degraded environments, such as agro-ecosystems, which can support viable populations of certain psittacine species (Bucher, 1992; Galindo, 1999; Romero, Naranjo, Morales, \& Nigh, 2006).

Identifying how forest fragmentation alters the distribution of different psittacid species is essential for the implementation of measures that are effective in mitigating its consequences. Research needs to be centered on ascertaining how these species respond to different levels of fragmentation, and which variables affect them the most. Parrots must be associated with large tropical forest areas and for the majority, the presence and distribution probability are associated with the most preserved areas characterized by little anthropogenic alteration. However, for some parrot species, habitat fragmentation can have positive effects at one scale and negative effects in another.

Eight species of psittacids inhabit the Yucatan Peninsula, Mexico, (MacKinnon, 2005), and several of these maintain abundant populations (e.g., Galindo, 1999; Macías \& Iñigo, 2003; Plasencia \& Escalona, 2014a). However, in this region of Southeast Mexico, the intensification of forest degradation and fragmentation (Turner II, Geoghegan, \& Foster, 2004) is threatening the viability of parrot populations. In the Peninsula, it is predicted that different levels of fragmentation cannot affect the distribution of parrot species with wide environmental tolerance (e.g. Amazona albifrons or Eupsittula nana), while the most affected will be those species with less environmental tolerance (e.g. Amazona farinosa or Pyrilia haematotis). Within this context, 
this study objective focused on determining the relationship between forest fragmentation and patterns of potential geographic distribution of psittacids inhabiting the Yucatan Peninsula.

\section{MATERIALS AND METHODS}

Study area: This study was carried out in the Mexican portion of the Yucatan Peninsula Biotic region which includes the states of Campeche, Quintana Roo and Yucatán $\left(17^{\circ} 0^{\prime}-21^{\circ} 35^{\prime} \mathrm{N} \& 86^{\circ} 43^{\prime}-92^{\circ} 25^{\prime} \mathrm{W}\right)$ (Barrera, 1962). The vegetation of the Yucatan Peninsula changes gradually along an environmental gradient associated with rainfall distribution patterns that stretch from the semiarid Northwest to the wetter Southeast. The changes in vegetation largely reflect rainfall patterns, with dry low deciduous scrub and semi-deciduous forest dominating towards the Northwest, and semiwet and tropical semi-evergreen forest predominant towards the Southeast (Pennington \& Sarukhán, 1998). By the 1990s, more than $60 \%$ of the Yucatan Peninsula was modified as a consequence of land use alterations, which led to widespread changes in vegetation distribution patterns (Carranza, Barreto, Molina, Bezaury, \& Loreto, 1996). The disappearance and fragmentation of forest areas within the Yucatan Peninsula continues, principally in the Southwest and Southeast regions (Turner II et al., 2004). The study was made between late June 2014 and September 2016, using database analyzes, without fieldwork. For analyzes, potential geographical distribution maps, land use and vegetation maps were used.

Study species and potential geographical distribution maps: The eight species of psittacids that inhabit the Yucatan Peninsula were studied: Olive-throated Parakeet (Eupsittula nana), White-fronted Amazon (Amazona albifrons), Yellow-lored Amazon (Amazona xantholora), Red-lored Amazon (Amazona autumnalis), White-crowned Parrot (Pionus senilis), Brown-hooded Parrot (Pyrilia haematotis), Yellow-headed Amazon (Amazona oratrix), and Southern Mealy Amazon
(Amazona farinosa) (MacKinnon, 2005). Within the Yucatan Peninsula, the greatest concentration of species occurred in the Southern area near the borders with Guatemala and Belize (Plasencia \& Escalona, 2014a). Amazona albifrons and E. nana are present almost in all Yucatan Peninsula. Amazona oratrix was only found in the Southwest portion of the Yucatan Peninsula. Amazona xantholora was present around much of the Peninsula, including the Cozumel Island, but it was absent in areas where A. oratrix was found. Amazona autumnalis, $P$. haematotis, $P$. senilis and A. farinosa were only located in wetter areas of the Southern portion of the Yucatan Peninsula.

There are no real distribution maps of the present psittacid species in the Yucatan Peninsula. Therefore, the models of potential geographical distribution published in 2014 were used (Plasencia, Escalona, \& Esparza, 2014a; Plasencia \& Escalona, 2014b). For A.xantholora and A. oratrix, the potential geographical distribution maps obtained by Plasencia et al. (2014a) were used. The distribution maps obtained by Plasencia and Escalona (2014b) were used for the remaining six species.

\section{Forest fragmentation in Yucatan Pen-} insula: A total of 15 digital files containing land use and vegetation maps from series IV of INEGI (National Institute of Statistics and Geography) were used to measure levels of forest fragmentation within potential psittacid distribution areas in the Yucatan Peninsula (INEGI, 2010). These maps cover the Mexican portion of the Yucatan Peninsula and were obtained for the period 2007-2010 (INEGI, 2010). The selected forest map included mangroves, petenes (islands of arboreal vegetation associated with freshwater springs), tropical forests and oak forest as these vegetation types are inhabited most frequently by parrot species. The remaining vegetation formations and land uses were eliminated from the study. All of the aforementioned forest types were grouped together, resulting in a map that represented the forest masses of the Yucatan Peninsula. 
All the above procedures were performed using the Arc View 3.2 software (ESRI, 1999).

One hundred hexagonal plots, each with $587 \mathrm{~km}^{2}$, were randomly distributed onto the potential geographical distribution map of each species. The hexagonal shape minimized the relationship area/perimeter without leaving any spaces (Mateucci \& Silva, 2005). The loss of vegetation cover and the processes of fragmentation had varied according to the particular region or state within the Yucatan Peninsula (Roy \& Turner II, 2006; Daniels, Painter, \& Southworth, 2008). Therefore the 100 plots covered a sufficiently large area (approximately $43 \%$ of total area of the Peninsula) as to represent the different levels of forest fragmentation within the Yucatan Peninsula. For each species, plots with $50 \%$ or more of the potential geographical distribution area occupied by one of the parrot species were classified as presence and the remaining as absence. The number of plots classified as absence (A) or presence $(\mathrm{P})$ for each species was the following: A. albifrons (five A, 95P), E. nana (seven A, 93P), A. xantholora (19A, 81P), A. autumnalis (64A, 36P), P. haematotis (57A, 43P), $P$. senilis (66A, 34P), A. farinosa (75A, 25P) and A. oratrix (98A, two $\mathrm{P})$.

Each one of the 100 plots that was classified as presence $(\mathrm{P})$ or absence $(\mathrm{A})$ for each parrot species, was used to superimpose onto the forest mass map; therefore, the same plots were obtained, but this time included information on the forest mass. These procedures were performed with the ArcView 3.2 Geoprocessing Wizard Extension (ESRI, 1999). A series of indexes were calculated for each plot using the ArcView 3.2 Patch Analyst Extension (ESRI, 1999). The indexes were selected to describe landscape fragmentation, characterizing the entire landscape as suggested by Fahrig (2003). We calculated the following variables: total forest area (TFA), number of patches (NP), mean patch size (MPS), patch size coefficient of variance (PSCV), patch size standard deviation (PSSD), total edge (TE), edge density (ED), mean patch edge (MPE), mean shape index (MSI), area-weighted mean shape index (AWMSI), mean perimeter-area ratio (MPAR), mean patch fractal dimension (MPFD), area-weighted mean patch fractal dimension (AWMPFD), Shannon's diversity index (SDI) and Shannon's evenness index (SEI) (see Elkie, Rempel, \& Carr, 1999).

Furthermore, the distance between patches (DP) and their spatial configuration were calculated. The shortest distance between the edge of one patch to another, and the distance between the centroids of all the patches were calculated for each plot. The sum of the crossed multiples of the matrixes of distances between the patch edges and their centroids was then calculated to obtain a distance summary variable. In order to acquire a measure of the spatial configuration of patches in the landscape, using the matrix of distances between the edges of the patches in each plot, the Moran's I Index (four and eight neighbors) (Moran, 1950) and the Geary's C index (four and eight neighbors) (Geary, 1954) were calculated by applying the ROOKCASE complement for Excel 97/2000 (Sawada, 1999), which determined the global and local spatial autocorrelation. When calculating the spatial autocorrelation, the dispersion level of the patches in each plot was determined, thus obtaining an approximation of how the patches were distributed throughout the landscape and whether any relationships or patterns existed in this distribution.

A Pearson's correlation was performed in order to reduce the collinearity between the fragmentation and spatial configuration variables used. Those variables with coefficients of $|\mathrm{r}|<0.7$ were selected (Dormann et al., 2012). Between the pairs of highly correlated variables, based on the natural history, habitat and knowledge obtained through field observations of these species, one of the variables that possibly has a strong relationship with psittacine distribution patterns in the Yucatan Peninsula was selected.

The four variables obtained to define the spatial configuration of patches was highlycorrelated ( $r>0.7)$. Only Moran's I Index with four neighbors was selected from these variables; this index was the most appropriate 
when carrying out analysis at the landscape level, as it produced the best measure of spatial autocorrelation at the global level. Moran's I Index values were not obtained for $12 \%$ of the plots given that they only contained one patch. A total of $51 \%$ and $29 \%$ of the plots, obtained positive and negative values, respectively, using Moran's I Index, indicating that at the scale of this study, there was a trend towards spatial clustering of patches that were found at similar distances from each other. The summary variable for distances was not correlated with any other variables $(r \leq 0.4 ; p>0.05)$. Among the fragmentation indexes, only the mean shape index, mean perimeter-area ratio and the mean patch fractal dimension were not highly correlated.

Once the highly-correlated variables were eliminated in order to reduce dimensionality in the analysis, a Principal Component Analysis (PCA) was applied. Out of the 21 initial variables, only 11 remained for the PCA: total forest area, number of patches, mean patch size, patch size standard deviation, mean patch edge, mean shape index, mean perimeter-area ratio, mean patch fractal dimension, Shannon's evenness index, distances between patches and Moran's I Index with four neighbors. The Varimax rotation method was implemented to minimize the number of variables and simplify their interpretation; subsequently, the components that explained $50 \%$ variability were selected. Variables that presented a factorial coefficient of more than 0.7 were then selected from these components. Subsequent to the Varimax rotation, the four first components explained $50 \%$ of the variability. With six variables, factorial coefficients greater than 0.7 were obtained for the first four components: total forest area, patch size standard deviation, mean patch edge, mean shape index, mean perimeter-area ratio and distance between patches.

A logistic regression (LR) was implemented to determine the possible relationship between the matrix of fragmentation and spatial configuration variables and the potential geographical distribution of the psittacid species (presence/absence maps). When applying the
LR, a Logit type model with a binary response and $95 \%$ confidence intervals was included. For best model selection, the Akaike information criteria (AIC) was used (Akaike, 1983) with a minimum and maximum of two and six variables, respectively. One hundred iterations with a convergence level of 0.000001 were carried out and second level interactions between variables were considered. In order to assess how good or bad these models were, the $\mathrm{Chi}^{2}$ test, associated with the Log ratio, was calculated. The Hosmer-Lemeshow test was used as an additional mean for evaluating the goodness of fit of the logistic regression models. For all the above analysis, the Excel XLSTAT (2013) complement was implemented.

\section{RESULTS}

No pattern was observed regarding the number of variables provided by the model and the potential geographical distribution area of the eight studied parrots in the Yucatan Peninsula. For the eight species, the best LR model was the one that presented the lowest value according to the Akaike Information Criteria (AIC). The number of resolved variables fluctuated between four and six (Table 1). In the case of $P$. haematotis and $A$. oratrix, the variables did not contribute to the regression model, and the $\mathrm{Chi}^{2}$ value for the intersection was significant (Table 2). At the scale used in this study, the potential geographical distribution of both of these species ( $P$. haematotis and $A$. oratrix) did not appear to show any relationship with the fragmentation variable; however, for the remaining six species, the $\mathrm{Chi}^{2}$ test demonstrated this relationship to be significant and different variables contributed significantly to the model (Table 2). But the "odds ratio" values were close to one for most of these variables or their interaction, thus any changes they experienced would have little effect on determining the presence or absence of some of these remaining six psittacids species. Overall, although the interactions between variables appeared to be more important, the "odds ratio" values indicated the contrary. 
TABLE 1

Best logistic regression models according to the Akaike Information Criterion (AIC) and its corresponding statistics, obtained through the fragmentation variables and the parrots potential geographical distribution models in the Yucatán Peninsula, Mexico

\begin{tabular}{lcccc}
\multicolumn{1}{c}{ Species } & \# of variables & $-2 \log$ (likelihood) & Pr $>$ LR & AIC \\
A. albifrons & 4 & 27.23 & 0.02 & 39.23 \\
P. haematotis & 4 & 100.94 & 0.00 & 112.94 \\
E. nana & 5 & 33.17 & 0.01 & 47.17 \\
A. xantholora & 5 & 71.84 & 0.01 & 85.84 \\
A. autumnalis & 5 & 85.35 & 0.00 & 99.35 \\
P. senilis & 5 & 87.05 & 0.00 & 101.05 \\
A. oratrix & 6 & 0.000 & 0.004 & 16.000 \\
\hline
\end{tabular}

-2 Log (likelihood): Likelihood ratio, Pr: Probability, LR: Likelihood ratio tests.

TABLE 2

Contributions of the fragmentation variables to the parrot's potential geographical distribution in the Yucatán Peninsula, according to the logistic regression models. It just includes the intersections, interactions and independent variables with significant contributions to the models

\begin{tabular}{llccccc}
\multicolumn{1}{c}{$\begin{array}{c}\text { Intersections/ interactions/ } \\
\text { independent variables }\end{array}$} & Coefficient & Chi & Pr>Chi & Odds ratio & $\begin{array}{c}\text { Odds ratio } \\
\text { inferior-superior limit (95\%) }\end{array}$ \\
PSSD*MPE & A. albifrons & -0.0004 & 3.8565 & 0.0496 & 0.9996 & $0.9992-1.0000$ \\
MPE*MSI & A. albifrons & 0.0445 & 3.9713 & 0.0463 & 1.0456 & $1.0007-1.0924$ \\
MPE & E. nana & 0.7329 & 6.7266 & 0.0095 & 2.0811 & $1.1961-3.6209$ \\
TFA*MPE & E. nana & -0.0010 & 6.3186 & 0.0119 & 0.9990 & $0.9983-0.9998$ \\
MPE*MSI & E. nana & -0.0717 & 7.2464 & 0.0071 & 0.9309 & $0.8835-0.9807$ \\
MSI & A. xantholora & -3.0847 & 5.1102 & 0.0238 & 0.0457 & $0.0032-0.6635$ \\
TFA*MPE & A. autumnalis & -0.0001 & 5.8271 & 0.0158 & 0.9999 & $0.9999-1.0000$ \\
TFA*MSI & A. autumnalis & 0.0052 & 6.4893 & 0.0109 & 1.0052 & $1.0012-1.0092$ \\
TFA*MPAR & A. autumnalis & 0.0010 & 5.3411 & 0.0208 & 1.0010 & $1.0001-1.0018$ \\
PSSD*MPAR & A. autumnalis & -0.0016 & 7.2687 & 0.0070 & 0.9984 & $0.9972-0.9996$ \\
MPAR & P. senilis & -1.1287 & 8.2671 & 0.0040 & 0.3235 & $0.1499-0.6982$ \\
TFA*MSI & P. senilis & -0.0034 & 5.8381 & 0.0157 & 0.9967 & $0.9939-0.9994$ \\
TFA*MPAR & P. senilis & 0.0032 & 10.1793 & 0.0014 & 1.0032 & $1.0012-1.0052$ \\
PSSD*MPAR & P. senilis & -0.0035 & 11.4066 & 0.0007 & 0.9965 & $0.9945-0.9985$ \\
MSI*MPAR & P. senilis & 0.1369 & 6.9237 & 0.0085 & 1.1467 & $1.0355-1.2697$ \\
PSSD & A. farinosa & 0.0176 & 8.5389 & 0.0035 & 1.0178 & $1.0058-1.0299$ \\
TFA*MPAR & A. farinosa & 0.0012 & 4.5067 & 0.0338 & 1.0012 & $1.0001-1.0024$ \\
PSSD*MPAR & A. farinosa & -0.0018 & 7.9253 & 0.0049 & 0.9982 & $0.9969-0.9994$ \\
Intersection & P. haematotis & -612.7559 & 0.0000 & $<0.0001$ & - & - \\
Intersection & A. oratrix & 8210.7309 & 0.0000 & $<0.0001$ & - & - \\
\hline
\end{tabular}

PSSD: patch size standard deviation, MPE: mean patch edge, MSI: mean shape index, TFA: total forest area and MPAR: mean perimeter-area ratio. Coefficient $(+)$ : the function is rising (the probability increases) and it is decreasing otherwise, Pr: Probability. Chi²: Chi-Square.

The distance between patches was the only variable that did not significantly influence the distribution of any of the species. The mean perimeter-area ratio contributed most frequently to parrot distribution; however, this variable only significantly influenced the distribution of P. senilis (Table 2).

Regarding the quality of the logistic regression models, in order to assess how good or bad these models were, one of the most important 
results is $\mathrm{Chi}^{2}$ associated with the Log ratio (Table 3). The fragmentation variables provided significant information for explaining the variability related to the presence/absence of six of the species (Table 3). The Hosmer-Lemeshow test proved that these results reaffirm another means of evaluating the goodness of fit of the logistic regression models. With this test, high $\mathrm{Chi}^{2}$ values $(\mathrm{p}<0.0001)$ were only obtained for $A$. oratrix and $P$. haematotis, which in this case signifies that for both of these species, the model does not present a good fit.

\section{TABLE 3}

Results of the likelihood ratio tests [-2 Log (likelihood)] to check up whether the reduced model is better than the full model, obtained through the fragmentation variables and the parrots potential geographical distribution in the Yucatán Peninsula

\begin{tabular}{lccc}
\multicolumn{1}{c}{ Species } & \# of variables & $\mathrm{Chi}^{2}$ & $\mathrm{Pr}>\mathrm{Chi}^{2}$ \\
A. albifrons & 4 & 11.39 & 0.02 \\
E. nana & 5 & 16.02 & 0.01 \\
A. xantholora & 5 & 15.39 & 0.01 \\
A. autumnalis & 5 & 29.23 & $<0.0001$ \\
P. senilis & 5 & 28.86 & $<0.0001$ \\
A. farinosa & 5 & 25.19 & 0.00 \\
P. haematotis & 4 & -2545.32 & - \\
A. oratrix & 6 & -6252.41 & - \\
\hline
\end{tabular}

Chi²: Chi-Square. Pr: Probability.

Only for E. nana, A. xantholora and $P$. senilis some variables were important in determining the distribution patterns (Table 2) and in general, showed that these parrot species had a preference to occupy sites that conserve large patches of vegetation. For E. nana, the variable that contributed the most was MPE (Table 2). The MPE gives us a measure of the degree of fragmentation and connectivity of the landscape and, the fact of obtaining positive values for the coefficient of this variable, means that the probability of distribution of E. nana increases as its values are higher. These higher values of MPE indicated that the areas in which E. nana species are most likely to be distributed, are less fragmented. In the case of $A$. xantholora, the variable that most contributed was MSI (Table 2). The MSI evaluates the shape complexity of a fragment. When a negative value of the coefficient for this variable is obtained (Table 2), the probability of distribution of $A$. xantholora is higher in areas with more regular forms, which often coincided with less fragmented sites. For P. senilis, the most related fragmentation variable to its potential distribution was MPAR (Table 2). A decrease in the fragments size is associated with an increase of the relationship perimeter/ area. When a negative value of the coefficient for MPAR is obtained, it can be interpreted that the potential distribution of $P$. senilis is favored in areas with larger fragments of forest.

\section{DISCUSSION}

When considering the scale at which this study was carried out, the selected fragmentation variables do not appear to be related to the potential distribution patterns of most parrot species found in the Yucatan Peninsula. This was not expected, as the fragmentation of the forest ecosystems has increased over the entire Peninsula, predominantly due to the loss of large forest tracts (Turner II et al., 2004). It has also been demonstrated, for some psittacid species, that ecosystem modifications caused by anthropogenic activities can actually be beneficial, as they often provide new sources of more accessible food (Sánchez, Ballari, Bucher, \& Masello, 2016). In the Calakmul region of the state of Campeche, large flocks of $A$. albifrons have been observed in perturbed areas; besides, this species is perceived as a pest by local peasant farmers, due to the damage they are thought to inflict on their cornfields (Galindo, 1999; Escalona \& Velasco, 2000). However, we cannot ignore that this only occurs for a little number of species, because parrots are among the most threatened bird orders with $28 \%$ of extant species classified as threatened under IUCN criteria (Olah et al., 2016).

Although different reports mention that fragmentation affects psittacid populations (e.g. Snyder et al., 2000; Forshaw, 2006), there are very few studies that state which variables 
are the most important or at what scale do they most frequently affect parrot species (e.g., Renton \& Salinas, 2004; Miller, Bianchi, Mullins, \& Haig, 2013; Plasencia, Escalona, \& Esparza, 2014b). Within the Yucatan Peninsula, it has been speculated that the scarlet macaw (Ara macao) had become locally extinct due to the accelerated destruction and fragmentation of high evergreen rainforest (Berlanga, Wood, Salgado, \& Figueroa, 2000); however, there is no empirical evidence that validates this. Most research has concentrated on habitat use or population dynamics of parrots in fragmented landscapes (e.g., Conti \& Galetti, 2007; Monterrubio, Ortega, \& Marín, 2009; Carneiro, Jiménez, \& White, 2012); therefore, since there is no solid basis to this question regarding psittacids, comparing results is problematic.

In the Yucatan Peninsula, the continual and rapid loss of forest areas (Vester et al., 2007) can affect the quality and quantity of potential habitats for Psittacidae species. The forests that have experienced the biggest vegetation cover loss are located in the Southeast and Southwest areas of the states of Quintana Roo and Campeche, respectively (Turner II et al., 2004); and most importantly, it is in these forests, where the highest diversity of parrot species is located (Plasencia \& Escalona, 2014a). Some of the species are only distributed in the Southern Yucatan Peninsula because of its humid climate, and the presence of humid to moist forest types.

This vegetation loss is causing an increase in isolation, reduction and degradation of the patches of remnant forests in the Yucatan Peninsula. Parrots in these areas may be affected mainly by the reduction and degradation of these limited remnant forest, since they do not fulfill all their requirements to stay and nest. Nevertheless, since parrots have high mobility, they are able to disperse over large areas, and may endure an increase in forest patch isolation (Munshi \& Wilkinson, 2006). On the other side, these landscape modifications have a negative influence on food and nesting sites requirements (Renton \& Salinas, 2004), and these have to be considered in future research efforts in the area.

Amazona oratrix is one of the most endangered parrot species in Mexico (Cantú, Sánchez, Grosselet, \& Silva, 2007), but none of the selected fragmentation variables were related to its potential distribution. In Mexico, one of the most prized species for the pet trade is A. oratrix; in the Yucatan Peninsula this parrot is only found in the Southwest, one of the most fragmented areas of the region, as a consequence of extensive livestock farming (Villalobos \& Mendoza, 2010). However, none of the selected fragmentation variables appear to be related to the potential distribution of this species, possibly due to the very small number of plots where this parrot occurs, considering the reduced area they inhabit and the scale of this study. Furthermore, Macías and Iñigo (2003) and Plasencia and Escalona (2014a) demonstrated that in the Yucatan Peninsula, this species presents one of the highest values of relative abundance in Mexico, indicating its capacity to survive even in perturbed areas. Nevertheless, the majority of parrot species presents high longevity (Munshi \& Wilkinson, 2006); therefore, changes in population numbers, attributable to the effects of environmental modifications such as fragmentation, only become evident over the long-term.

Before drawing conclusions, it should be taken into account that, as $A$. oratrix was only represented in a small number of plots, in which the levels of fragmentation were high, it was not possible to establish a comparison between areas with different characteristics. If the analysis is only based on areas with similar characteristics, it is difficult to determine whether fragmentation may or may not influence the distribution of the species. It would be necessary to expand the study area for this species, in order to obtain a larger number of plots on which to perform the analysis. Although, as far as the distribution of $A$. oratrix is known in Mexico, the remnant areas where it is still found are mostly fragmented and degraded habitats (Macías \& Iñigo, 2003), what keeps making this type of analysis difficult. 
Eupsittula nana, P. senilis and A. xantholora presented a relationship between some fragmentation variables and their potential distribution, indicating a preference by these species for larger patches of habitat, a characteristic that has also been determined for other species of birds (Davis, 2004). Even though, psittacids have the ability to adapt to anthropic habitat modifications, many of these species are normally associated with areas dominated by conserved forest that provide them with suitable sites for feeding and reproduction (Morales, 2005; Monterrubio \& Escalante, 2006).

In the case of $A$. xantholora, one of the fragmentation variables demonstrated a marked influence on the potential distribution of this species (mean shape index), indicating that at the scale used, this particular species is more sensitive to the fragmentation process. The results determined that the mean shape index negatively affects the presence of this species in the Yucatan Peninsula, indicating that with an increase in patch irregularity there is an associated decrease in the probability of finding this species. In different areas subject to high levels of anthropic pressure throughout the Yucatan Peninsula, forest patches tend to be smaller in area and more irregular in shape.

The results obtained in this study partially support the theory which responds that fragmentation vary among different species (see Visco et al., 2015; Uezu \& Metzger, 2016). When performing this type of research, it is necessary to previously determine which scale is most suitable for each species. However, the results also reinforce the fact that fragmentation is scale dependent, and the effects of habitat fragmentation depend on the size of the landscape considered (see Smith et al., 2011). Future research on the relationship between fragmentation and potential geographical distribution of different parrot species in the Yucatan Peninsula, should consider smaller scales of study and the inclusion of other environmental variables (e.g. land use, vegetation types, spatial configuration) in the analysis (e.g. Plasencia et al., 2014b). Fragmentation is a process that is directly related to the loss of vegetation cover (one of its principal causes) and land use changes (surrounding the patches), and, a particular combination of both of these factors, could provide the key to explain psittacid distribution patterns.

The most important recommendation for managers and users of protected areas within the Yucatan Peninsula is that extensive areas of forest should be maintained in order to guarantee the survival of psittacid populations. One of the most important challenges facing the conservation of parrots in the fragmented landscapes of the Yucatán Peninsula, is the existing imbalance between ecosystem transformation and the speed at which decisions are taken at the private, state and federal level. Forest areas sometimes experience extremely rapid changes, while at the same time management decisions require lengthy processes for the assignation of conservation priorities. However, as psittacids are charismatic birds, they could potentially act as "flagship species", promoting actions to preserve the habitats where they are present in the Peninsula. Moreover, protecting these psittacids would indirectly contribute to protect a multitude of other species that make up the ecological community of their habitats, and so acting as "umbrella species".

\section{ACKNOWLEDGMENTS}

We are grateful to D. Denis, K. Renton and L. G. Esparza for their helpful comments. Thanks to INEGI for providing the Land Use and Vegetation Maps of the Yucatan Peninsula. Thanks to CONACYT for the economic support provided through the grants 239499 and 21467. Thanks to the manuscript reviewers for their valuable suggestions and comments. Finally, we would like to thank Idea Wild for the donated equipment.

\section{RESUMEN}

Relación entre la fragmentación forestal y la distribución geográfica potencial de los psitácidos (Psittaciformes: Psittacidae) en la Península de Yucatán, México. Los psitácidos se encuentran seriamente 
amenazados por el tráfico ilegal de mascotas y la destrucción y fragmentación de su hábitat. El objetivo de este estudio fue determinar la relación entre la fragmentación y los patrones de distribución geográfica potencial de las especies de psitácidos de la Península de Yucatán, México. El estudio se realizó en la porción mexicana de la Provincia Biótica Península de Yucatán, que incluye los estados de Campeche, Quintana Roo y Yucatán. Se estudiaron las ocho especies de psitácidos que habitan la Península de Yucatán: Eupsittula nana, Amazona albifrons, Amazona xantholora, Amazona autumnalis, Pionus senilis, Pyrilia haematotis, Amazona oratrix y Amazona farinosa. Para las ocho especies se utilizaron los mapas de distribución geográfica potencial publicados en la literatura en el 2014, obtenidos con el algoritmo de máxima entropía (MaxEnt). Los mapas de uso de suelo y vegetación de la serie IV (2007-2010) del Instituto Nacional de Geografía y Estadística se usaron para medir los niveles de fragmentación de las selvas en la Península de Yucatán. Se calcularon diferentes métricas del paisaje en 100 parcelas distribuidas al azar dentro de las áreas de presencia y ausencia predichas para las especies. Se emplearon métodos multivariados para reducir dimensionalidad en los análisis, así como para explorar los patrones observados. No se encontró ningún patrón en cuanto al número de variables que aportan a los modelos de regresión logística (RL) y el tamaño del área de distribución geográfica potencial de los loros en la Península. Para Pyrilia haematotis y Amazona oratrix, la escala de trabajo con las variables de fragmentación, no parecen tener relación con su distribución geográfica potencial en la Península (intersección, $\operatorname{Pr}<0.0001$ ). Solo para Eupsittula nana, Amazona xantholora y Pionus senilis se comprobó que la media del borde del fragmento, el índice medio de forma y la media de la proporción área-perímetro son importantes para determinar sus patrones de distribución respectivamente y en general apuntan una preferencia de estos loros por ocupar sitios que conservan fragmentos grandes de vegetación. Se le debe prestar mucha atención a la protección de los psitácidos en los estados de Campeche y Quintana Roo por ser áreas con una alta diversidad de loros y una zona altamente impactada por las actividades humanas. La recomendación más importante para los administradores y usuarios de las áreas protegidas dentro de la Península de Yucatán es que se deben mantener extensas áreas forestales para garantizar así la persistencia de las poblaciones de psitácidos.

Palabras clave: conservación, especies amenazadas, factores ambientales, loros, modelos de nicho ecológico, Sureste de México.

\section{REFERENCES}

Akaike, H. (1983). Information measures and model selection. International Statistical Review, 44, 277-291.
Arroyo, V., \& Fahrig, L. (2014). Why is a landscape perspective important in studies of primates? American Journal of Primatology, 76, 901-909. doi: 10.1002/ ajp. 22282

Barrera, A. (1962). La Península de Yucatán como provincia biótica. Revista de la Sociedad Mexicana de Historia Natural, 23, 71-150. Retrieved from http://repositorio.fciencias.unam.mx:8080/xmlui/ bitstream/handle/11154/142692/23VPeninsulaYucat an.pdf? sequence $=1$

Berlanga, M., Wood, P., Salgado, J., \& Figueroa, E. M. (2000). Calakmul, AICA. In M. C. Arizmendi \& L. Márquez (Eds.), Áreas de Importancia para la Conservación de las Aves en México (pp. 110-111). México D. F.: CIPAMEX.

Bregman, T. P., Sekercioglu, C. H., \& Tobias, J. A. (2014). Global patterns and predictors of bird species responses to forest fragmentation: Implications for ecosystem function and conservation. Biological Conservation, 169, 372-383. Retrieved from http:// dx.doi.org/10.1016/j.biocon.2013.11.024

Brennan, J. M., Bender, D. J., Contreras, T. A., \& Fahrig, L. (2002). Focal patch landscape studies for wildlife management: optimizing sampling effort across scales. In J. Liu \& W. W. Taylor (Eds.), Integrating Landscape Ecology into Natural Resource Management (pp. 68-91). Cambridge: Cambridge Univ. Press. Retrieved from http://www.glel.carleton.ca/ pdf/landPub/02/02BrennanetalLiuBook.pdf

Bucher, E. (1992). Neotropical parrots as agricultural pests. In S. R. Beissinger \& N. F. R. Snyder (Eds.), New World parrots in crisis. Solutions from conservation biology (pp. 201-219). New York, USA: Smithsonian Inst. Press.

Cantú, J. C., Sánchez, M. E., Grosselet, M., \& Silva, J. (2007). Tráfico ilegal de pericos en México. Una evaluación detallada (Reporte Final). México: Defenders of Wildlife. Retrieved from http://www. pericosmexico.org/pdf/ReporteFinalEspanol.pdf

Carneiro, A. P. B., Jiménez, J. E., \& White Jr., T. H. (2012). Post-fledging habitat selection by the Slender-Billed parakeet (Enicognathus leptorhynchus) in a fragmented agricultural landscape of Southern Chile. The Condor, 114, 166-172. Retrieved from https://www. fws.gov/caribbean/pdf/post fledginghabselection.pdf

Carranza, J., Barreto, C., Molina, C., Bezaury, J., \& Loreto, A. (1996). Análisis cartográfico del cambio de uso del suelo en la península de Yucatán, México. México: Amigos de Sian Ka'an.

Cintra, R., Magnusson, W. E., \& Albernaz, A. (2013). Spatial and temporal changes in bird assemblages in forest fragments in an eastern Amazonian savannah. Ecology and Evolution, 3(10), 3249-3262. Retrieved from https://www.ncbi.nlm.nih.gov/pmc/articles/ PMC3797474/ 
Conti, M. F., \& Galetti, M. (2007). Use of forest fragments by blue-winged macaws (Primolius maracana) within a fragmented landscape. Biodiversity and Conservation, 16, 953-967. doi: http://dx.doi. org/10.1007/s10531-006-9034-9

Daniels, A., Painter, K., \& Southworth, J. (2008). Milpa imprint on the tropical dry forest landscape in Yucatan, Mexico: Remote sensing and field measurement of edge vegetation. Agriculture, Ecosystems and Environment, 123, 293-304. doi: http://dx.doi. org/10.1016/j.agee.2007.07.003

Davis, S. K. (2004). Area sensitivity in grassland passerines: effects of patch size, patch shape, and vegetation structure on bird abundance and occurrence in Southern Saskatchewan. The Auk, 121, 1130-1145. doi: http:// dx.doi.org/10.1642/0004-8038(2004)121[1130:ASIG $\mathrm{PE}$ 2.0.CO;2

Dormann, C. F., Elith, J., Bacher, S., Buchmann, C., Carl, G., Carré, G., ... Lautenbach, S., (2012). Collinearity: a review of methods to deal with it and a simulation study evaluating their performance. Ecography, 35, 001-020. doi: 10.1111/j.1600-0587.2012.07348.x

Elkie, P. C., Rempel, R. S., \& Carr, A. P. (1999). Patch analyst user's manual a tool for quantifying landscape structure (Technical Manual TM-001). Thunder Bay: Ontario Ministry of Natural Resources NWST.

Escalona, G., \& Velasco, J. (2000). La milpa maya y el impacto de las aves y mamíferos en sistemas de producción agrícolas. Edzná, 42, 7-8.

ESRI (1999). ArcView 3.2. Redlands, CA, USA: ESRI (Environmental Scientific Research Institute).

Fahrig, L. (2003). Effects of habitat fragmentation on biodiversity. Annual Review of Ecology, Evolution, and Systematics, 34, 487-515. doi: 10.1146/annurev. ecolsys.34.011802.132419

Forshaw, J. M. (2006). Parrots of the World: an identification guide. Princeton, Princeton University Press.

Galindo, C. (1999). La gran región de Calakmul: Prioridades biológicas de conservación y propuesta de modificación de la Reserva de la Biosfera (Reporte Final). México, D.F.: Center for Conservation Biology. Retrieved from http://www.ecovivero.org/ calakmul.pdf

Geary, R. C. (1954). The contiguity ratio and statistical mapping. The Incorporated Statistician, 5, 115-146. Retrieved from http://www.jstor.org/stable/2986645

Inegi. (2010). Conjunto de datos vectoriales de la carta de uso del suelo y vegetación: escala 1:250 000. Serie IV (continuo nacional). Aguascalientes, México: Instituto Nacional de Estadística y Geografía. Recuperado de http://www.inegi.org.mx/geo/contenidos/recnat/ usosuelo/
Lees, A. C., \& Peres, C. A. (2009). Gap-crossing movements predict species occupancy in Amazonian forest fragments. Oikos, 118, 280-290. doi: 10.1111/j.1600-0706.2008.16842.x

Legault, A., Chartendrault, V., Theuerkauf, J., Rouys, S., \& Barre, N. (2011). Large-scale habitat selection by parrots in New Caledonia. Journal of Ornithology, 152, 409-419. doi: 10.1007/s10336-010-0602-0

Macías, C. M., \& Iñigo, E. E. (2003). Evaluación del estado de conservación actual de las poblaciones de loro cabeza amarilla (Amazona oratrix) en México (Informe final del proyecto AS002 apoyado por la Comisión Nacional para el Conocimiento y Uso de la Biodiversidad, CONABIO). México, D. F.: Instituto Tecnológico y de Estudios Superiores de Monterrey. Retrieved from http://www.conabio.gob.mx/institucion/proyectos/resultados/InfAS002.pdf

Major, R. E., Christie, F. J., \& Gowing, G. (2001). Influence of remnant and landscape attributes on Australian woodland bird communities. Biological Conservation, 102, 47-66. doi: http://dx.doi.org/10.1016/ S0006-3207(01)00090-8

McGarigal, K., \& Cushman, S. A. (2002). Comparative evaluation of experimental approaches to the study of habitat fragmentation effects. Ecological Applications, 12, 335-345. Retrieved from https://www. umass.edu/landeco/pubs/mcgarigal.cushman.2002. pdf

MacKinnon, B. (2005). Birds of Yucatan Peninsula. Cancún, México: Amigos de Sian Ka’an, AC.

Marín, M. C., Monterrubio, T. C., Renton, K., Rubio, Y., Macías, C., Cancino, R., \& Ortega, J. M. (2012). Reduced current distribution of Psittacidae on the Mexican Pacific coast: potential impacts of habitat loss and capture for trade. Biodiversity and Conservation, 21, 451-473. doi: 10.1007/s10531-011-0193-y

Mateucci, S. D., \& Silva, M. (2005). Selección de métricas de configuración espacial para la regionalización de un territorio antropizado. GeoFocus, 5, 180-202. Retrieved from http://www.geofocus.org/index.php/ geofocus/article/view/65/233

Metzger, J. P., Camargo, A., Dixo, M., Bernacci, L. C., Ribeiro, M. C., Godoy, A. M., \& Pardini, R. (2009). Time-lag in biological responses to landscape changes in a highly dynamic Atlantic forest region. Biological Conservation, 142, 1166-1177. doi: http:// dx.doi.org/10.1016/j.biocon.2009.01.033

Miller, M. P., Bianchi, C. A., Mullins, T. D., \& Haig, S. M. (2013). Associations between forest fragmentation patterns and genetic structure in Pfrimer's Parakeet (Pyrrhura pfrimeri), an endangered endemic to central Brazil's dry forests. Conservation Genetics, 14, 333-343. doi: 10.1007/s10592-012-0420-4 
Monterrubio, T. C., \& Escalante, P. (2006). Richness, distribution and conservation status of cavity nesting birds in Mexico. Biological Conservation, 128, 67-78. doi: http://dx.doi.org/10.1016/j.biocon.2005.09.017

Monterrubio, T. C., Ortega, J. M., \& Marín, Ma. C. (2009). Nesting habitat of the Lilac-crowned Parrot in a modified landscape in Mexico. Biotropica, 41, 361368. doi: 10.1111/j.1744-7429.2009.00493.x

Morales, L., (2005). Evaluación de la abundancia poblacional y recursos alimenticios para tres géneros de psitácidos en hábitats conservados y perturbados de la costa de Jalisco, México (Tesis inédita de maestría). Universidad Nacional Autónoma de México, D.F., México.

Moran, P. A. P. (1950). Notes on continuous stochastic phenomena. Biometrika, 37, 17-23. doi: 10.2307/2332142

Munshi, J., \& Wilkinson, G. S. (2006). Diet influences life span in parrots (Psittaciformes). The Auk, 123, 108118. Retrieved from http://www.life.umd.edu/faculty/ wilkinson/South\&Wilk06.pdf

Olah, G., Butchart, S. H. M., Symes, A., Medina, I., Cunningham, R., Brightsmith, D. J., \& Heinsohn, R. (2016). Ecological and socio-economic factors affecting extinction risk in parrots. Biodiversity and Conservation, 25(2), 205-223. doi: 10.1007/ s10531-015-1036-Z

Pennington, T. D., \& Sarukhán, J. (1998). Árboles tropicales de México. Manual para la identificación de las principales especies. México: Universidad Nacional Autónoma de México, Instituto de Ecología, Fondo de Cultura Económica.

Plasencia, A. H., Escalona, G., \& Esparza, L. G. (2014a). Modelación de la distribución geográfica potencial de dos especies de psitácidos neotropicales utilizando variables climáticas y topográficas. Acta Zoológica Mexicana, 30, 471-490. Retrieved from http://www. scielo.org.mx/pdf/azm/v30n3/v30n3a2.pdf

Plasencia, A. H., Escalona, G., \& Esparza, L. G. (2014b). Interaction of landscape variables on the potential geographical distribution of parrots in the Yucatan Peninsula, Mexico. Animal Biodiversity and Conservation, 37.2, 191-203. Retrieved from http://abc. museucienciesjournals.cat/files/ABC_37-2_pp_191203.pdf

Plasencia, A. H., \& Escalona, G. (2014a). Relative Abundance of Parrots throughout the Yucatan Peninsula: Implications for their Conservation. The Wilson Journal of Ornithology, 126, 759-766. doi: http://dx.doi. org/10.1676/13-206.1

Plasencia, A. H., \& Escalona, G. (2014b). Caracterización del área de distribución geográfica potencial de las especies de aves psitácidas de la Península de Yucatán, México. Revista de Biología Tropical,
62, 1509-1522. doi: http://dx.doi.org/10.15517/rbt. v62i4.13576

Renton, K. (2001). Lilac-Crowned Parrot diet and food resource availability: resource tracking by a parrot seed predator. The Condor, 103, 62-69. doi: http:// dx.doi.org/10.1650/0010-5422(2001)103[0062:LCP DAF]2.0.CO;2

Renton, K., \& Salinas, A. (2004). Climatic variability, nest predation, and reproductive output of lilac-crowned parrots (Amazona finschi) in tropical dry forest of western Mexico. The Auk, 121, 1214-1225. doi: http:// dx.doi.org/10.1642/0004-8038(2004)121[1214:CVN PAR]2.0.CO;2

Romero, K. G, Naranjo, E. J., Morales, H. H., \& Nigh, R. B. (2006). Daños ocasionados por vertebrados silvestres al cultivo de maíz en la selva lacandona, Chiapas, México. Interciencia, 31(4), 276-283. Retrieved from http://www.scielo.org.ve/scielo.php?script=sci_arttex t\&pid=S0378-18442006000400007

Roy, R., \& Turner II, B. L. (2006). Reconciling agency and structure in empirical analysis: smallholder land use in the Southern Yucatán, Mexico. Annals of the Association of American Geographers, 96, 302-322. doi: $10.1111 /$ j.1467-8306.2006.00479.x

Sánchez, R., Ballari, S. A., Bucher, E. H., \& Masello, J. F. (2016). Foraging by burrowing parrots has little impact on agricultural crops in northeastern Patagonia, Argentina. International Journal of Pest Management, 65, 1-10. Retrieved from http://dx.doi.org/1 $0.1080 / 09670874.2016 .1198061$

Sawada, M. (1999). Technological tools. Rookcase: an Excel 97/2000 visual basic (VB) add-in for exploring global and local spatial autocorrelation. Bulletin of the Ecological Society of America, 80, 231-234. doi/10.1890/0012-9623(1999)080\%5b0231:TT\%5d2 $.0 . \mathrm{CO} \% 3 \mathrm{~b} 2 / \mathrm{epdf}$

Smith, A. C., Fahrig, L., \& Francis, C. M. (2011). Landscape size affects the relative importance of habitat amount, habitat fragmentation, and matrix quality on forest birds. Ecography, 34, 103-113. doi: 10.1111/j.1600-0587.2010.06201.x

Snyder, N., McGowan, P., Gilardi, J., \& Grajal, A. (2000). Parrots. Status survey and conservation action plan 2000-2004. UK: IUCN/SSC Action Plans for the Conservation of Biological Diversity. Retrieved from https:/www.parrots.org/publications-and-fact-sheets/ parrot-action-plan

Tella, J. L., Dénes, F. V., Zulian, V., Prestes, N. P. Martínez, J., Blanco, G., \& Hiraldo, F. 2016. Endangered plantparrot mutualisms: seed tolerance to predation makes parrots pervasive dispersers of the Parana pine. Scientific Reports, 6, 1-11. doi: 10.1038/srep31709

Turner II, B. L., Geoghegan, J., \& Foster, D. R. (2004). Integrated land-change science and tropical deforestation in the Southern Yucatán: Final Frontiers. United 
Kimgdom: Oxford University Press. Retrieved from http://bibliotecasibe.ecosur.mx/sibe/book/000032695

Uezu, A., \& Metzger, J. P. 2016. Time-lag in responses of birds to Atlantic forest fragmentation: restoration opportunity and urgency. PLoS ONE, 11(1), e0147909. doi:10.1371/journal.pone.0147909

Vester, H. F. M., Lawrence, D., Eastman, J. R., Turner II, B. L., Calmé, S., Dickson, R., ... Sangerman, F. (2007). Land change in the Southern Yucatán and Calakmul Biosphere Reserve: effects on habitat and biodiversity. Ecological Applications, 17, 989-1003. doi: 10.1890/05-1106

Villalobos, G. J., \& Mendoza, J. (2010). La Biodiversidad en Campeche: Estudio de Estado. Campeche,
México: Comisión Nacional para el Conocimiento y Uso de la Biodiversidad (CONABIO), Gobierno del Estado de Campeche, Universidad Autónoma de Campeche, El Colegio de la Frontera Sur, México. Recuperado de http://www.biodiversidad.gob.mx/ region/EEB/pdf/Biodiversidad_Campeche_baja.pdf

Visco, D. M., Michel, N. L., Boyle, W. A., Sigel, B. J., Woltmann, S., \& Sherry, T. W. (2015). Patterns and causes of understory bird declines in human-disturbed tropical forest landscapes: A case study from Central America. Biological Conservation, 191, 117-129. doi: http://dx.doi.org/10.1016/j.biocon.2015.05.018

XLSTAT. (2013). Software, Version 2013.1. Copyright Addinsoft 1995-2013. Retrieved from http://www. xlstat.com/es/ 